УДК 004

https://doi.org/10.47533/2020.1606-146X.06

\author{
N. M. TEMIRBEKOV ${ }^{*}$, D. R. BAIGEREYEV ${ }^{2}$, A. N. TEMIRBEKOV ${ }^{3}$ \\ ${ }^{1}$ Kazakhstan University Of Engineering And Technology \\ ${ }^{2}$ Sarsen Amanzholov East Kazakhstan University \\ ${ }^{3}$ Al-Farabi Kazakh National University
}

\title{
USING THE RESOURCES OF A DISTRIBUTED INFORMATION SYSTEM FOR SOLVING APPLIED PROBLEMS
}

\begin{abstract}
The process of designing and creating an integrated distributed information system for storing digitized works of scientists of research institutes of the academic city of Almaty, carried out within the framework of the grant project of the Ministry of Education and Science of the Republic of Kazakhstan AP05131806. The requirements for the storage of digital objects are defined. The system fully provides the necessary computing resources for ongoing research and educational processes, simplifying the prospect of its further development, and allows to build an advanced IT infrastructure for managing intellectual capital, an electronic library that is intended to store all books and scientific works of the Kazakhstan Engineering Technological University and research institutes of the Almaty academic city.
\end{abstract}

Key words: Server, IT infrastructure, IT solutions, Big Data, portal, supercomputer.

Introduction. Today, technological progress requires an unlimited growth rate of computing and information capacities of post-petaflops scales, providing new fundamental knowledge and innovation in the production, environmental, economic and social spheres. In this regard, mathematical modeling of processes and phenomena is rapidly developing, including theoretical and applied research, super-calculations and large-scale computer experiments, operations with super-large data, and artificial intelligence. The solution of such problems requires large amounts of software of a new generation of architectural solutions and constructive technologies. Global trends lead to the creation of integrated computing and information surroundings that form a tool environment for automating the construction of models and algorithms, displaying them on super computer platforms, and creating comfortable interfaces for users with different professional training. Such an ecosystem is designed for a long-life cycle with continuous development and coordinated participation of various development groups. In fact, it leads to the formation of a new industry with mass professions of high supercomputer literacy. The identified scientific and technological challenges require competent organizational and infrastructure solutions, including interdepartmental coordination of academic, educational and production teams [1].

Despite the harmonious development of various socio-economic trends in the twentyfirst century, the importance of these trends is obvious. The role of these technologies has dramatically increased after the mass appearance of personal computers, and then in connection with the birth of multiprocessor computers of the teraflops and petaflops level with $10^{12}-10^{15}$ operations per second. The rate of increase in computer capacity obeys the law of G. Moore, one of the founders of the company "Intel" - exponential growth of 1000 times in 11 years. Although saturation should have already occurred according to physical laws, the anomalous dynamics remain. Currently, the record-breaking supercomputer has about 200 petaflops, and the appearance of exaflops ( $10^{18}$ arithmetic actions per second) already takes place. Such a multiprocessor computing system will have hundreds of millions 
of computing devices, and the generation now entering working life will have access to super-calculations of a fundamentally new scale. There is an ability to store and process huge amounts of numeric data [1].

One of the main tasks of the economy is the task of the agro-industrial complex. The use of multiprocessor computers for solving problems of the agro-industrial complex is very necessary. The use of information technologies allowed the agro-industrial complex to reach a new level, increase efficiency and solve strategically important issues. The use of big data in agriculture is rapidly developing. It will allow farmers to increase their harvest.

First, technologies for remote sensing of the earth, precision agriculture, technologies for visualizing space data on the map, rapid access to high-detail images for accurate mapping of field boundaries and crop rotations, fertility zones, and monitoring of vegetation conditions are becoming promising [2]. This uses data from satellites, sensors, and other systems.

Second, the introduction of digital technologies into the library collections and archives of research institutes in the agro-industrial sector is of great applied importance. Creating a digital representation of library resources makes it possible not only to ensure their preservation for many centuries, but also to provide them to a wide range of people. It should be recognized that most of the works published before the middle of the XX century by scientists have not been widely distributed due to the lack of a single repository or scientometric databases.

Third, systems of online control of elements of the production cycle and management of agro-business: machinery, fields and warehouses are relevant. These systems process data about the weather, vegetation index, soil condition, and crop rotation. For example, the Russian project "Agrosignal" [3], which connects more than 150 farms that process more than 2 million hectares of land, focuses mainly on crop control.

Fourth, specialized information services containing catalogs and knowledge bases, as well as observational data, play an important role. These services are often used for publishing news and analytical articles, allowing employees of the agro-industrial sector to discuss pressing issues and share their experience.

Research material and methods. Each of these directions, as a rule, leads to the need for efficient storage of the resulting data array. In the Russian Federation, there are several dozen information services dedicated to the agro-industrial complex. For example, there are portals agroyug.ru, agrofoodinfo.com, webpticeprom.ru, agbz. ru, latifundist.com, agroserver.ru, rynok-apk.ru, agrobook.ru, agro.ru, ya-fermer.ru, agro2b.ru, agroxxi.ru intended for people whose activities are related to agriculture and corresponding goods and services. These portals are distributed to the clients from Russia, Belarus, Moldova, Ukraine, China, Europe and abroad. The sites contain catalogs of companies, manufacturers, products and services, price lists, events, and articles. Thus, these information services provide the population with high-quality content in the field of agro-industrial complex, which helps to solve many problems of producers and consumers of the agro-industrial complex. In the Republic of Kazakhstan, there are very few information services dedicated to IT solutions in the agro-industrial complex. The website of the information and agricultural newspaper "Agro info" agroinfo.kz provides 
information on agronomy, animal husbandry, new agricultural machinery and equipment, explanations of legislation, overview of the grain market, answers to readers ' questions. The portal agrobiz.kz is aimed at improving the effectiveness of systematic interaction of the farming community with government agencies, organizations, financial institutions, the market sector and the population. The idea of the portal is to provide farmers from remote regions a direct access to the open market, increase demand for their products in many ways, and block the path of numerous intermediaries. The portal is intended to become a single database of all farms and rural districts, hundreds of agricultural scientists and experts, and thousands of agricultural enterprises in the country. There is an agro. $\mathrm{kz}$ portal for publishing ads in the agricultural sector. Recognizing the need to create a similar resource for researchers and employees of the agro-industrial complex, a team of scientists from the Kazakhstan University of engineering and technology, "Academset» LLP and number of research institutes created the portal of the academic city of Almaty - acagor.kz. This system is aimed at solving the following tasks:

- creation of a single repository of scientific articles, monographs, geographical materials, audio and video recordings and other results of intellectual activity of employees of research institutes in the field of agro-industrial complex;

- providing flexible search for necessary information on metadata of documents and their contents;

- organization of information collection on remote digital repositories and from scientometric databases;

- placement of news, business and advertising information and the possibility of information exchange.

The system allows you to keep the results of intellectual activity of research institutes up-to-date and provides access to them on the basis of Web technologies. The created portal corresponds to the "Industry 4.0" strategy, which aims to transfer new technologies to the agro-industrial complex of the Republic of Kazakhstan and search for practical innovative solutions to eliminate factors that limit the development of agriculture in Kazakhstan.

The agroindustrial complex, due to numerous reasons and global trends, is the most important area where these technologies can and should be implemented. Despite the fact that the introduction of information technologies in the agro-industrial sector has always been quite difficult, the new round of technological development has given a strong impetus to the use of the latest digital technologies in this sector of the economy [4].

«Industry 4.0» is a new approach to production, which is formed on the collection of big data. The use of "Big Data" technology helps farmers save more and earn more money. Figure 1 shows a structural diagram of the distributed information system of Akademgorodok.

Only recently introduced into industrial production, high-volume data processing allows you to optimize product quality, save energy, and improve the performance of your equipment. In the context of" Industry 4.0", the collection and comprehensive evaluation of data obtained from various sources - from production equipment, ERP (Enterprise Resource Planning) and CRM systems of the enterprise (Customer Relationship Management), will become a standard tool for supporting real-time decision-making[4]. 


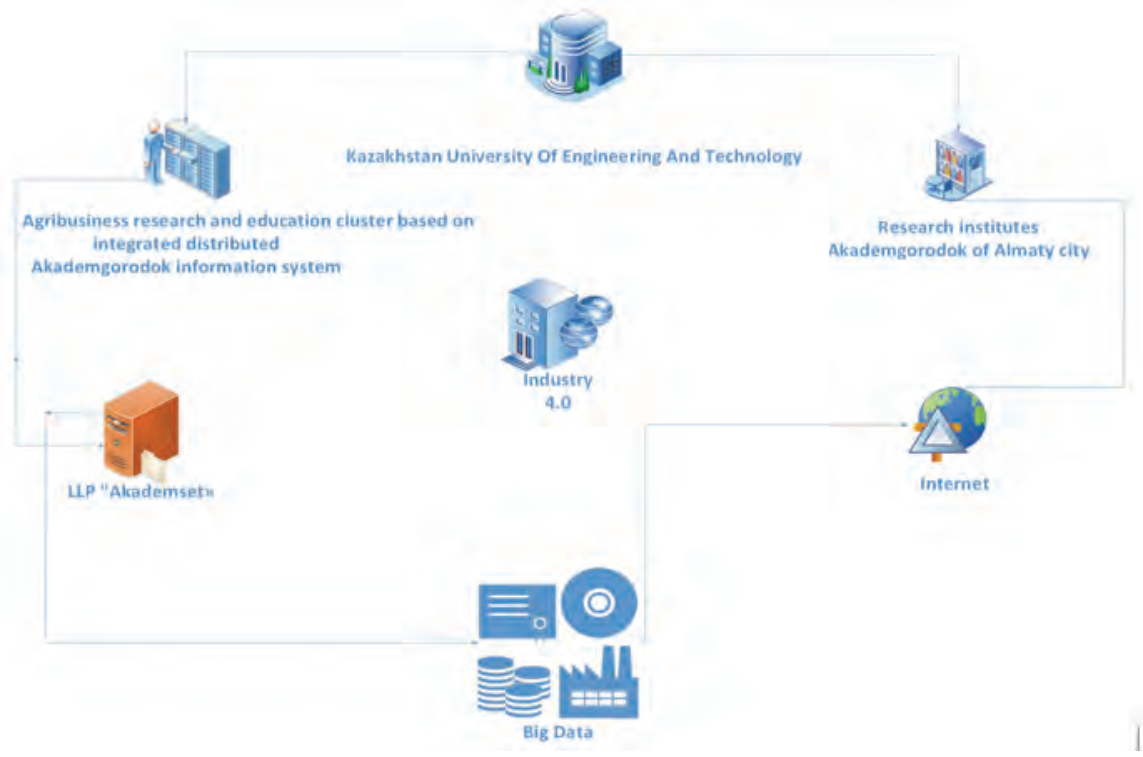

Figure 1 - Block diagram of the distributed information system of Akademgorodok

Today, the authors of the portal set a goal to create a multiprocessor computing cluster within the portal. With the help of it various tasks will be solved in the industrial, environmental, economic and social spheres.

One of these tasks is the task of studying and predicting the epidemiological situation of COVID-19 coronovirus infection. Experts from different fields of science are divided in their opinion on how long the pandemic will last. The Atlantic analyzed and accounted for 4 of the most probable scenarios [5].

The first and second scenarios assumed that the coronavirus would last from one month to four months. A part of the medical community was sure that the coronavirus would not be a serious pathogen. Unfortunately, during this time, the coronovirus did not go down, and the pandemic continues to grow. The third scenario assumed that the pandemic would last up to one year, and the fourth more than a year. These forecasts do not have a clear time frame for the end of the pandemic. They are made analytically.

The research and forecasting methods are devoted to the joint use of mathematical models and real data, which is an effective tool for studying complex epidemiological processes and solving practical problems based on it. Related tasks play a significant and important role here. Direct and feedback links between models and daily real data on the spread of coronavirus and the system organization of computing technologies are convenient to build using variational principles. This approach naturally leads to the combined use of forward and reverse modeling methods.

The approach based on the classical Lagrange variational principle using conjugate equations is the most promising for solving problems of estimating and predicting virus propagation processes.

For a more accurate prediction of the epidemiological situation, it is necessary to develop a mathematical model for the spread of COVID-2019 coronavirus and develop a computational 
algorithm for a multiprocessor computing cluster. This will allow us to more accurately describe the epidemiological situation around the world. The diagram of interaction between the Akademgorodok portal and the computer system is shown in figure 2.

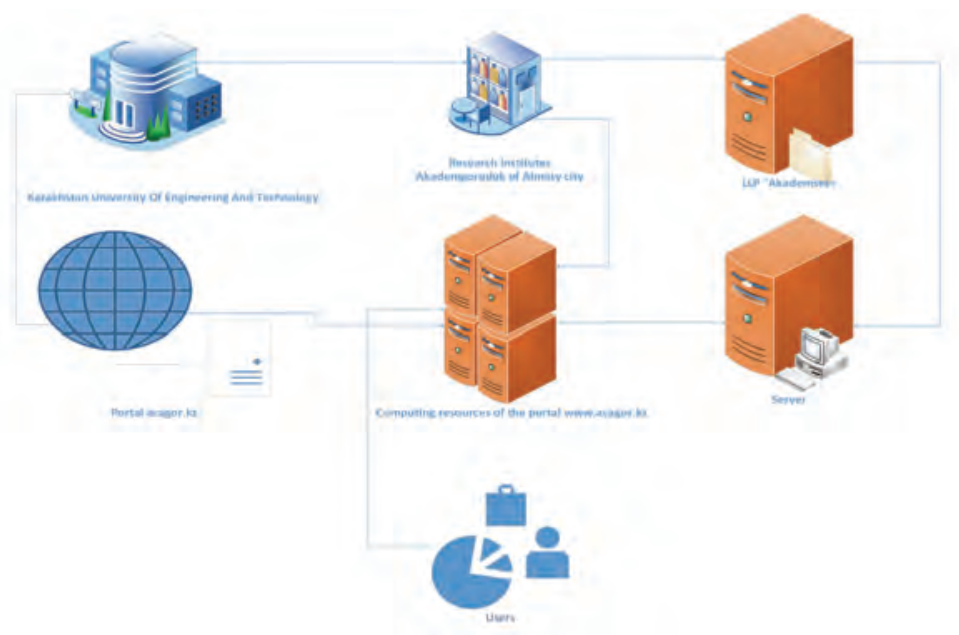

Figure 2 - Block diagram of a computer system based on the Akademgorodok portal

Today, the system allows you to store the following information:

- information about research organizations;

- information about the employee of research organizations, different spellings of his name, including in different languages;

- links to profiles in various databases (Scopus, Researcher ID, ORCID);

- information about research activities (participation in funded projects, conferences, internships, etc.).

The web portal is designed to provide a standardized unified user interface for all functions and modules that are part of a distributed information system. The portal part provides remote access to information resources and services. The subsystem combines the processes of providing access to information resources to all interested subjects of interaction. The provision of services involves:

- navigation through services;

- access to project information and regulatory legal and methodological materials;

- user identification, authentication, and authorization;

- providing basic information about research institutes and their employees;

- providing information about the latest achievements of research institutes, upcoming events, conferences;

- availability of photo and video galleries;

- personal account, analysis of working hours on the site, storage of request history;

- managing requests for searching for authors and titles of publications;

- managing requests for full-text search on resources;

- export data to various formats;

- providing various reports. 
Results and discussions. Built information system used to store digitized articles, monographs and technical reports of the staff of the Institute of General genetics and Cytology, Institute of human physiology and animals of the Kazakh research Institute of processing and food industry Kazakh research Institute of fruit growing and viticulture Kazakh scientific research Institute of soil science and Agrochemistry named after U. U. Uspanov, Kazakhstan engineering-technological University, Research Institute of Microbiology and Virology. The repository is filled in by content managers (employees of the research Institute and the Kazakhstan University of engineering and technology) according to the model presented in [6]. As a result of integration of the web portal with the repository of digital objects, metadata and links to materials uploaded to the storage subsystem are displayed on the scientist's profile page and on the information page of research institutes [7-11]. You can search by metadata. In addition, filtering by keywords, institutions, date and language of publication is implemented. Currently, more than 936 works are stored in the repository.

The software implementation of the research integration and support module is based on the interaction of the web application with the scientometric database API with further data analysis and systematization. To do this, a table was created containing the digital IDs of each employee of the research Institute:

- Scopus author ID;

- ID of the Web of Science researcher;

- Google Scholar citation profile;

- ORCID.

These identifiers are being filled by the managers of the content web applications. Main functions of the created module:

- getting a list of publications of research Institute employees;

- synchronize information with profiles of the scientists on the website of the campus;

- display of publications of the research Institute;

- displaying the number of links to publications and calculating the scientist's h-index with or without self-citation;

- reporting that reflects the assessment of the effectiveness and efficiency of the research Institute, the output of structured current and comparative data on scientometric indicators of employees. This function takes into account reporting periods for comparative analysis by quarter, year, and five years;

- export data to various formats.

Note that the h-index is not returned on request. Its calculation is based on the analysis of the list of publications and their citations.

In General, the developed module saved the research Institute employees from the routine manual work of extracting and analyzing information from scientometric databases.

The web portal contains many software modules. With the help of the conference module developed for the Web portal, which was successfully tested at the international conference in April 2019, it is planned to hold an international scientific and practical conference "Computational and Information Technologies in Science, Engineering and Education" (CITech-2020), dedicated to the 1150th anniversary of al-Farabi (Almaty, October 9-10, 2020). All designated papers selected by the international expert Council of the conference 
are planned to be published in a collection of articles in the Springer publishing house in the series "Communications in Computer and Information Science" (indexed in the Scopus database) and also to the repository of digital objects of the Web portal acagor. kz. Taking into account the work done, the authors of the integrated distributed system in the future set a goal to create a multiprocessor computing cluster within the portal. With the help of which various tasks will be solved in the industrial, environmental, economic and social spheres.

Gratitudes. The work was supported by grant funding of scientific and technical programs and projects by the Ministry of education and science of the Republic of Kazakhstan (grant № AP05131806, 2018-2020).

\section{REFERENCES}

1 Ilyin V. P. How to reorganize computer science and technology// Bulletin of the Russian Academy of Sciences, 2019, V. 89, № 3. - P. 232-242.

2 RKS and "RUSAGRO" unite the efforts for the digitalization of agriculture of Russia [Electron. resource]. - 2017. - URL: https://www.roscosmos.ru/24458/ (accessed 15.08.2020).

3 Agrosignal - GLONASS / GPS system for monitoring special equipment and agro-business management [Electron. resource]. 2019. - URL: https://7gis.ru/podderzhka/platformyi/agrosignal. html (accessed 15.08.2020).

4 Tuskov A. A., Grosheva E. S., Palatkin I. V., Shorokhova O. S. industry 4.0 in agriculture: main trends in the application of Internet of things technologies in agriculture // Models, systems, and networks in Economics, technology, nature, and society. - 2018. - № 1 (25). - C. 55-64.

5 Zhivaya Kuban online diary of the Krasnodar territory [Electron. resource]. - 2020. - URL: livekuban.ru/news/obshchestvo/skolko-budet-dlitsya-epidemiya-koronavirusa/(accessed 15.08.2020).

6 Shokin Yu. I., Temirbekov N. M., Zhizhimov O. L., Temirbekov A. N., Baigereev D. R. Model of the integrated distributed library information system of the academic city of Almaty // Computing technology. - 2018. - V. 23. - №. 5. - P. 110-119.

7 Temirbekov N., Baigereyev D., Temirbekov A., Smolarz A. Architecture of the distributed information system of the Almaty Akademgorodok / / Przeglad Elektrotechniczny. - 2019. - №. 5. P. 75-78.

8 Temirbekov N. M., Zhizhimov O. L., Baigereev D. R., Omirzhanova B. B., Temirbekov A. N., Orazgalieva A.m. Building a scientific and educational cluster based on the integrated distributed information system of Akademgorodok // Joint issue of the journals "Bulletin of EKSTU named after D. Serikbayev"and “Computing technologies”. - 2018. - V. 1., №. 3., Part 1. - P. 120-127.

9 Temirbekov N. M., Baigereev D. R., Temirbekov A. N. Cloud technologies for the organization of scientific and educational agro-industrial cluster of the academic city of Almaty / / Bulletin of alFarabi KazNU, series "mathematics, mechanics, Informatics", no. 3(103), 2019. - P. 75-89.

10 Temirbekov, N., Baigereyev, D., Temirbekov, A., Omirzhanova, B. Development of an information system for storing digitized works of the Almaty Academic research institutes (Conference Paper). AIP Conference Proceedings. Volume 2183, Article number 080005.-2019.

11 Temirbekov N.,Baigereyev D., Temirbekov A., Omirzhanova B. Development of a Distributed Information System of the Almaty Academgorodok. Journal of Engineering Science and Technology Review Special Issue on Telecommunications, Informatics, Energy and Management 2019.-p.127130. 


\title{
Н. М. ТЕМИРБЕКОВ
}

${ }^{1} 1$ Казахстанский инженерно-технологический университет

${ }^{2}$ Восточно-Казахстанский университет имени Сарсена Аманжолова

${ }^{3}$ Казахский национальный университет им. аль-Фараби, Алматы, Казахстан

\section{ИСПОЛЬЗОВАНИЕ РЕСУРСОВ РАСПРЕДЕЛЕННОЙ ИНФОРМАЦИОННОЙ СИСТЕМЫ ДЛЯ РЕШЕНИЯ ПРИКЛАДНЫХ ЗАДАЧ}

\begin{abstract}
Проанализирован процесс проектирования и создания интегрированной распределенной информационной системы для хранения оцифрованных трудов ученых научно-исследовательских институтов Академгородка города Алматы, проводимые в рамках грантового проекта МОН РК АР05131806. Определены требования к хранилищу циифровых объектов. Система в полной мере обеспечивает необходимыми вычислительными ресурсами проводимые научные исследования и образовательные прочессы, упрощая перспективу дальнейшего его развития, и позволяет построить передовую IT-инфраструктуру управления интеллектуальным капиталом, электронной библиотекой, в которых будут храниться все книги и научные труды Казахстанского инженернотехнологического университета и научно-исследовательских институтов Академгородка города Алматьл.
\end{abstract}

Ключевые слова: сервер, IT-инфраструктура, IT-решения, Big Data, портал, суперкомпьюmep.

\section{Н. М. ТЕМІРБЕКОВ ${ }^{1}$, Д. Р. БАЙГЕРЕЕВ ${ }^{2}$, А. Н. ТЕМІРБЕКОВ}

${ }^{1}$ Қазақустан инженерлік-технологияльқ университеті

${ }^{2}$ Сәрсен Аманжслов атындавы Шыгыс Қазақстан Университеті

зәл-Фараби атындавы Қазақ ұлттық университеті, Алматы, Қазақстан

\section{ҚОЛДАНБАЛЫ ЕСЕПТЕРДІ ШЕШУ ҮШІН ТАРАТЫЛҒАН АҚПАРАТТЫҚ ЖУЙЕНІН РЕСУРСТАРЫН ПАЙДАЛАНУ}

Мақұалада ҚР БжҒМ гранттық құаржыландырылган АР05131806 жобасы аясында жүргізілген Алматы құласы Академияльқ қалашыгының вылылми-зерттеу институттары гальмдарының uуифрланган еңбектерін сақтау үшін біріктірілген таратылган ақппараттық жүйені жобалау және құру процесі талданды. Сандық объектілерді сақтауга құйылатын талаптар анықталды. Жүйе жүргізілетін выльми зерттеулер мен білім беру процестерін оның одан әрі даму перспективасын оңайлата отырып, қажетті есептеу ресурстарымен толық көлемде қамтамасыз етеді және зияткерлік капиталды басқарудың озық IT-инфрақұрылылылн, электрондық кітапхананы құруга мүмкіндік береді, онда Қазақстан инженерлік-технологияльқ университетінің және Алматы құласы Академқалашывының выльми-зерттеу институттарының барльқ кітаптары мен выльлми енуектері сақталатын боладыл.

Түйін сөздер: сервер, IT-инфрақұрылым, IT-шешімдер, Big Data, портал, суперкомпьютер. 